\title{
U. Busse
}

\section{LOGOS, JESUS EN GOD IN JOHANNES 1:1-5: 'N TEKSTUELE ANALISE}

\author{
LOGOS, JESUS AND GOD IN JOHN 1:1-5: A TEXTUAL ANALYSIS
}

\begin{abstract}
In this article, the relationship between Christology and theology in John 1:1-5 is addressed. In particular, the relationship between the Logos and God has to be clarified. It is suggested that this relationship should be understood in the sense of communication between the Logos and God. This could then be interpreted further as that the Logos performed creation and the rest of God's plans.
\end{abstract}

\section{INLEIDING}

Dit wil voorkom of alles wat 'n mens oor die Johannesproloog probeer skryf, steeds maar 'n voorlopige poging sal bly. Dit mag vir vele lyk of die sentrale vraag wat in hierdie artikel ondersoek word, naamlik of die Proloog die sentrum van sy uitsprake in die Christologie of in die teologie vind, reeds opgelos is. ${ }^{1}$ Vir diesulkes is dit nie 'n kwessie van 'n keuse tussen alternatiewe nie; die twee aspekte vloei vir hulle ineen. Die Logos van die geloof, wat met die historiese Jesus identies is, is vir hulle vanselfsprekend God, naamlik die Christus, die Seun van God (20:31).

1 U.C. von Wahlde (2010:395-397) stel teologie gelyk aan Christologie.

Prof. U. Busse, Navorsingsgenoot, Fakulteit Teologie, Noordwes Universiteit. E-posadres: ulrich.busse@uni-due.de 
'n Opmerking van C.K. Barrett (1982:4) wat lank gelede gemaak is, naamlik:

There can be no doubt then that for John the historical figure of Jesus was central for his understanding of God; central, but not final,

plaas egter 'n vraagteken agter hierdie tese. Wat hier volg, is 'n hernieude poging om hierdie sentrale vraagstelling te verdiep deur ' $n$ analise van Johannes 1:1-5 met gepaardgaande suggesties vir die verstaan van hierdie betekenisvolle teks. Die skerp afgebakende beginpunte van elke strofe verdeel die poëtiese Proloog, wat in sterk gestruktureerde taal ${ }^{2}$ geskryf is, in drie dele, ${ }^{3}$ naamlik 1:1-5; 1:6-13 en 1:14-18.

\section{JOHANNES 1:1 EN DIE LOGOS}

V. 1 open programmaties met 'n intertekstuele verwysing na Genesis 1:1. Deur vv. 6-8 word v. 1 in 'n historiese gebeurteniskonteks geplaas en vanaf v. 14 verwys 'n nuwe "ons"-subjek terug na hierdie gebeurtenis en beklemtoon in himniese taal die heilswins wat daaruit voortvloei. Hierdie eerste vers veronderstel dus die eerste Bybelse skeppingsberig, maar stel ook 'n nuwe figuur, die Logos, bekend, wat in die oorspronklike skeppingsberig nog onbekend was. Volgens Genesis 1:1 het God, "in die begin", alleen die hemel en die aarde geskep. Aangesien daar eers vanaf v. 3 in die Proloog oor die eintlike skeppingswerk verslag gelewer word, beskryf vv. 1-2 dus 'n fase wat voor enige beginpunt lê, naamlik die "oeraanvanklike" voorbereidings op die eintlike begin. In hierdie voorbereidings speel die Logos 'n belangrike rol. Die teks gee geen inligting oor sy herkoms nie. Hierdie vraag word gereserveer vir latere metafisiese spekulasie oor die moontlike pre-eksistensie van die Logos. ${ }^{4}$ Die outeur is

2 Meer uitvoerig uiteengesit in Busse (2002:58-61).

3 Hier moet reeds daarop gewys word dat die Proloog nie vanuit 'n moontlike ontstaansgeskiedenis nie, maar as literêre eenheid geïnterpreteer behoort te word. Die tese wat dikwels voorgehou word, naamlik dat verse 6-8 en 15 as sekondêre toevoegings gesien en dus nie as deel van die Proloog beskou behoort te word nie, aangesien dit na Johannes as getuie verwys, laat m.i. die literêre en teologiese impak van hierdie verse binne die algehele struktuur van die teks buite rekening.

4 Daarom moet 'n mens ook skepties wees wanneer Weder (2008) sy eksegetiese Christosentrisme, wat reeds in die titel van sy werk herkenbaar is, na die "on-vooruitdenkbare" wil uitbrei. In die Proloog gaan dit veel eerder om die betekenis van die Logos in sy verhouding tot die enige God en ook tot die skepping. 
slegs geïnteresseerd in die voorbereidings op die skepping "in die begin" en nie "voor die begin" nie. Dit is duidelik dat die Logos hier reeds in die milieu divin 'n sentrale rol speel.

In die tweede deel van die sin word hierdie rol getematiseer: aan die een kant versluierd, aan die ander kant tog duidelik dekodeerbaar.

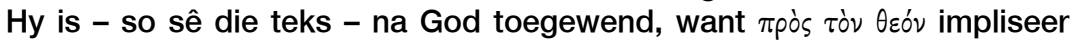
hoegenaamd nie $\pi a \rho \dot{\alpha} \tau \tilde{\omega} \theta \varepsilon \tilde{\omega}$, "by God", nie. Laasgenoemde sou uitsluitlik sy ruimtelike nabyheid aan God beklemtoon. Eersgenoemde omskryf eerder 'n kommunikatiewe situasie tussen twee Persone, 'n toewending na mekaar. In 'n gespreksituasie draai 'n mens tog nie van die spreker af weg nie, maar oriënteer jouself juis na hom toe. ${ }^{6}$ Die Skepper-God het die Logos dus vir kommunikatiewe kontak waardig bevind; vervolgens word 'n persoonlike verbinding gemaak en word $\mathrm{Hy}$ so bo alles, sover dit die skepping betref, uitgelig. Die moontlike situasie is dus as volg: God voer 'n intieme gesprek met die Logos oor die skepping wat Hy beplan. So word die Logos vir die eerste keer ingewy in die skeppingsopset en die omvattende skeppingskonsepsie van God en daarmee ook in sy uiteindelike oogmerke. Uit vv. 3-5 word dit ook duidelik watter rol die Logos in sy beplanning speel: Hy moet dié plan tot uitvoer bring. So word God uitgebeeld as die Bouheer en Argitek, en die Logos as die Boumeester van die skepping. Beide staan van die begin af in die verhouding gekenmerk deur 'n lewendige uitruil van idees met mekaar (vgl. 1:51; 5:177). Om sy deel van die skeppingswerk suksesvol te kan doen, het die Logos egter die kreatiewe krag van God nodig. Hy bly dus van God afhanklik en handel nie eiemagtig nie, maar hou Hom aan die plan wat vooraf deur beide bespreek is.

Met hierdie insig kan 'n mens nou die derde, teologies so omstrede skakel in die ketting van v. 1 minder bevooroordeeld benader. Verrassend genoeg word die Logos hier met die doelbewus beklemtoonde titel "God" - sonder lidwoord - benoem. Hierdie lidwoordlose predikaatsnomen is

5 A. von Harnack (1892:216) het reeds hierop gewys.

6 B. Weiss (1912:3) interpreteer hierdie aspek reeds so. Hy vertaal dit as: "in lebendigem Verkehr mit". Vgl. ook Weiss (1893:ad loc.), asook die interpretasie van B.F. Westcott (1900:ad loc.). Meer aktueel H. Dörrie (1979:148, vn. 148) en C.H. Giblin (1985:90, vn. 9). Hy verwys na die Goddelike kommunikasie met die profete (Hos. 1:1; Joël 1:1; Jona 1:1; Sef. 1:1 en Sag. 1:1 e.d.m.) as moontlike parallelle. Teen M. Theobald (2009:110) wat hierdie aspek miskyk, wat ook filologies belangrik is, en verkeerdelik praat van 'n "räumliche Metaphorik," wat "die größtmögliche Nähe des Logos zu Gott" moet beskryf.

$7 \quad$ R.A. Culpepper (1983:34) skryf hieroor: "The gospel narrative therefore portrays Jesus as the one who continued the creative work of the divine Logos..." 
oop vir verskillende interpretasiemoontlikhede. ${ }^{8}$ 'n Mens kan dit, soos dit gewoonlik die geval is, as gelykstellingsnominatief met "en God was die Logos" vertaal. Verdere moontlike vertalings is "goddelik was die Logos" of "'n god was die Logos" of ook "Godsgeaard was die Logos". Laasgenoemde kom meer dikwels voor. ${ }^{9}$ Die eerste vertaling impliseer dat die Logos met God self identies is. Die tweede verswak hierdie stelling ietwat deur die gekose adjektief. Die derde vertaling verhef die Logos tot ' $n$ tweede god. Hierdie alternatief druis aan die een kant radikaal in teen die Joodse monoteïstiese voorstelling wat in die Evangelie heers, maar aan die ander kant stem dit ooreen met die aanklag wat dikwels vanuit die Jodendom en Islam teen die Christelike oortuiging gemaak word. Die laaste vertalingspoging wil beklemtoon dat daar in wesenlike areas 'n ooreenstemming tussen die Logos en God is. Dié vertaling betoon ook die wesenseenheid van die Logos en God wat uit hierdie ooreenstemming afgelei kan word.

Hierdie verskeidenheid van vertalingsmoontlikhede in 'n teologies uiters sensitiewe konteks, vereis die honorering van vaste grammatikale reëls ${ }^{10}$ ten einde meer argumente vir een van die vertalingsmoontlikhede te kan vind. Weiss ${ }^{11}$ kon hierdie filologiese opsies nog in 1911 betwis en het na die konteks verwys: die konteks sou die Godgelykheid van die Logos onmoontlik maak en die aangeleentheid word daardeur tot 'n wesensgelykheid beperk. Dit is eers die invloedryke werk van Colwell wat die tersaaklike grammatikale reëls getoets het. Hy kom tot die gevolgtrekking dat daar kontekstueel niks teen die geloofsbelydenis

8 Toonaangewend vir hierdie diskoers is die bydraes van B. Weiss (1911:322-323), E.C. Colwell (1993:12-21), P.B. Harner (1973:75-87) en E.L. Miller (1981:65-77).

9 Vgl. slegs die kommentare van O. Holtzmann (1887), W. Heitmüller (1908), J. Schneider (1978), E. Haenchen (1980), en B. Schwank (1996), asook die artikel van P. von der Osten-Sacken (1994:147).

10 Colwell (1993:12-21) en Harner (1973:75-87) het die grammatikale reëls soos volg vasgelê: 1. 'n Bepaalde predikaatsnomen neem altyd die lidwoord; 2. Wanneer ' $n$ ander woordorde egter doelbewus aangewend word, ontbreek die lidwoord by die predikaatsnomen wat die werkwoord voorafgaan; 3. Eiename neem geen lidwoord nie; 4 . Nominatiewe predikaatsnomina in relatiewe bysinne neem die lidwoord; 5. 'n Predikaatsnomen word voor die werkwoord geplaas wanneer dit 'n kategorie of klas beskryf waarvan die subjek 'n voorbeeld is (bv. Mk 7:26); en 6. Die predikaatsnomen kan ook vooropgestel word wanneer dit met die subjek uitruilbaar is (bv. Mk 12:7). In laasgenoemde geval moet die kwaliteit (geval 5) wat die predikaatsnomen vanuit die konteks bekom, in gedagte gehou word.

11 Weiss (1911:319): "denn eine sprachliche Regel, die man aus dem griechischen oder semitischen Sprachgebrauch ableiten könnte, kann es dafür nicht geben." Eksegete is dus op konteks en op analogieë aangewese. 
spreek nie. Die uitspraak kan dus wel as 'n bevestiging van die eenheid van die Logos met God gesien word. Hiermee weerspreek hy die vorige eksegetiese konsensus, wat uitstekend deur Weiss (1911:322-323) geformuleer is: "Allgemein anerkannt ist wohl heutzutage, daß in dem

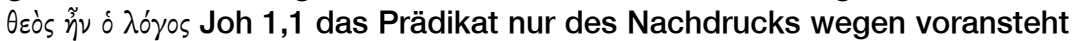
und nicht etwa die Identität Gottes und des Logos ausgesprochen ist, da eben noch in dem $\pi$ pòs tòv $\theta$ róv beide als miteinander im Verkehr stehend, also als verschiedene persönliche Subjekte bezeichnet sind."12 Hierna het Harner (1973) nog probeer om Colwell met sy eie wapens te beveg, deurdat hy die filologiese resultate in twyfel getrek het. Volgens hom het die 53 lidwoordlose predikaatsnomina vóór en ná die werkwoord in die Johannesevangelie ten minste 'n "qualitative significance" (Harner 1973:84) - wat hy interpreteer as "the nature [wese] that the $\lambda$ óyos shared with God, and $\delta \theta \varepsilon o ́ s$ as a 'person' to whom the $\lambda \dot{o} \gamma o \varsigma$ stood in relation. Only

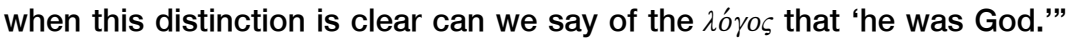
(Harner 1973:87). Hiermee het hy weer na die vroeëre resultate van Weiss teruggekeer. Hierdie gedetailleerde onderskeid tussen "persoon" en "wese" laat egter die gees van 'n latere filosofies-ontologiese denkmodel herkenbaar word, wat nie werklik in 'n vroeg-Joodse konteks inpas nie. Die vroeë Jodedom dink oorwegend ${ }^{13}$ in dinamiese en nie in filosofiese kategorieë nie. Hierdie aspek moet beter in ag geneem word by die eerste vers wat na die (Joodse) skeppingskonteks terugverwys. Die eerste en tweede versdele praat oor dié tydpunt waarop God die Logos in sy vertroue geneem het aangaande sy skeppingsvoornemens. Die uitspraak van die derde versdeel moet by hierdie konteks pas. Dit is nie nodig dat hierdie derde versdeel 'n Christologiese wesensdefinisie van die Logos moet probeer aanbied nie - dit word in hierdie vorm glad nie eens verwag nie, omdat dit hier slegs daarom gaan dat die skepping hoegenaamd op dié wyse moontlik gemaak word.

\section{DIE LOGOS WAT SKEP}

Volgens v. 3 het God die wêreld "deur die Logos"14 geskep (vgl. o.a. Carter 1990:37). Dit sou vir die Logos egter slegs moontlik gewees het as Hy,

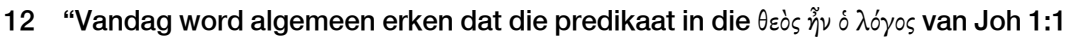
net ter wille van beklemtoning vooropstaan en dat die identiteit van God en die Logos nie daarmee verwoord word nie, aangesien beide pas nog met $\pi \rho \dot{s} s$ tò $\theta$ cóv aangedui word as onderskeidelike persoonlike subjekte wat met mekaar in interaksie staan."

13 Afgesien van Filo van Alexandrië en ander geleerde Diaspora-Jode.

14 Volgens Sir. 39:21 (vgl. 1QS 4:24; EthHen 39:11) "is alles vir 'n bepaalde doel bestem," d.w.s. ook die Logos. 
soos aangetoon het, met die nodige kreatiewe kragte en bypassende omvattende vaardighede toegerus sou wees. Volgens Genesis 1:1 beskik slegs God oor hierdie kragte en vaardighede. Daaruit volg dan logies dat God die Logos vooraf daarmee toegerus het, anders sou Hy nie God se uitvoerende "orgaan" kon word nie. Hy alleen is vir die praktiese deel van die skeppingsproses verantwoordelik, en daarom wil dit vanuit die erkenningsperspektief van die geskape wêreld ${ }^{15}$ - waartoe ons almal behoort - voorkom asof Hy die Skepper van alles, die Skepper-God, is. Uit die perspektief van God is Hy egter slegs in 'n oordragtelike sin "God". In hierdie ontipiese gebruik van die substantief ${ }^{16}$ "God" het nie net Origenes nie, maar ook destydse filosowe en verdere vroeg-Christelike teoloë die geleentheid gesien om enersyds die Hellenistiese konings- of ook die Romeinse keiserkultus verstaanbaar en draaglik te maak. Andersyds wou hulle hiermee die verwyt van 'n Christelike diteïsme filologies weerlê. ${ }^{17}$

Die opvallende samevattende aard ${ }^{18}$ van die tweede vers spreek ook vir die feit dat dit die bedoeling is dat daar in die derde versdeel van $\mathbf{v}$. 1 reeds na die skepping vooruitverwys word. V. 2 raak naamlik nie die skeppingsaspek aan nie, maar keer eerder terug na die uitgangspunt in die oeraanvang. Gevolglik is die eintlike skepping die resultaat van die ontmoeting en gespreksvoering tussen God en die Logos. Verder is God, volgens die uitspraak van v. 18, onkenbaar; slegs die Logos, wat daar "sy Seun" genoem word, het hom in woord en daad in sy leeftyd outentiek "bekendgestel". Uit die perspektief van God, daarteenoor, was die Logos (slegs) sy innigste vertroueling, wat volgens die uitspraak van v. 1b getrou alles moes uitvoer wat Hom meegedeel en beveel is. ${ }^{19}$ Hierdie insig in die

15 Ook die outeur van die Proloog het sigself dus as geskapene verstaan.

16 10:34-35 toon duidelik dat die Evangelis met die oordragtelike gebruik van die woord "God" vertroud was.

17 Hieroor het N. Brox twee belangrike bydraes gemaak, wat die ontwikkeling van hierdie idee naspeur: Brox (1996:3-46; en 2000:426-429). Daarnaas behoort die ontwikkeling van die Logos-idee in die tweede tot vierde eeu, wat die teologie in die algemeen gevorm het, ook in ag geneem te word. Hierdie ontwikkeling word uitstekend uiteengesit in die feesbundel vir E. Früchtel: Prostmeier \& Lona (2010).

18 G. Korting (1989:98) het reeds spesifiek na die formele parallel in v. 3b verwys en daarnaas die samevattende funksie van v. 2 beklemtoon. Veel vroeër reeds het G.A. van den Berg van Eysinga (1909:143) ook nog daarop gewys "daß [auch hier] der Logos in vorweltlicher Zeit in ganz naher, lebendiger Beziehung zu Gott stand."

19 Von Harnack (1892:197) formuleer dit vaardig en treffend: "Aus diesem Willen, der der Wille der Liebe ist, stammt die Sendung des Sohnes. Die vollkommene Einheit von Vater und Sohn hebt dieses Verhältniß nicht auf, vielmehr ist sie selbst das Produkt göttlichen Willens in Bezug auf den Sohn." 
dubbele perspektief van die programmatiese drieledige opening van die Proloog dwing ons tot die vertaling van die derde deel as "en vir die wêreld was 'God' die Logos." 20 Die Onherkenbare word naamlik vir die menslike wêreld indirek in die Skepper-Logos openbaar.

Dit is dus eers in v. 3 dat gesê word dat die wêreld deur die Logos geskep word. Die klem lê hier op die betekenis van die Logos vir die wêreld. Hy is

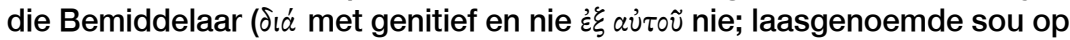
die Skepper dui); Hy is die uitvoerende Orgaan van God, en aldus vir die wêreld en die wêreldgeskiedenis God. Die werkwoord $\gamma^{\prime}(v \varepsilon \sigma \theta a \iota$ word hier op analoë wyse as in die LXX-weergawe van die Bybelse skeppingsberigte gebruik. Hierdie gebruik van $\gamma^{\prime}(v \varepsilon \sigma \theta a$ l beklemtoon nie net die skeppingswerk self nie, maar ook die gevolge wat daaruit voortspruit. ${ }^{21}$ Wanneer die skepping ' $n$ aanvang neem, begin daarmee saam ook die skeppings- of wêreldgeskiedenis. In die tweede versdeel van v. 3 word saam met oủ $\delta \dot{\varepsilon} \varepsilon^{22} v^{22}$ ook nog deur die gebruik van $\chi \omega$ pís die alleenverantwoordelikheid van die Logos vir absoluut "alles" 23 in die skeppingsgebeure onderstreep.

\section{DIE LIG EN LEWE IN JOHANNES 1:4-5}

Hiermee sou die uitspraak passend afgesluit kon gewees het - alles is tog gesê. Sedert die derde eeu word daar egter geredeneer of die volgende versdeel nog tot v. 3 behoort of reeds tot v. 4 gereken behoort te word. ${ }^{24}$ Die tweede lesing is inderdaad die moeilikere en 'n mens sou alle probleme kon vermy indien ' $n$ mens $H$. Thyen sou volg wat, soos vele voor hom, die relatiewe bysin tot v. 3 wil reken. ${ }^{25}$ In dié geval sou sekere grammatikale en inhoudelike nuanses egter verlore gaan, terwyl dit behoue bly wanneer die relatiewe bysin as begin van die volgende vers (vers 4) geneem word. E. Schwartz (1907/1908:534) het reeds ten opsigte van die stilistiek van die uitgebreide sin opgemerk dat as die relatiewe bysin die voortsetting van v. 3 sou wees, dit nie net inhoudelik toutologies sou wees nie, maar dat 'n

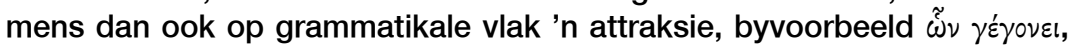
te wagte sou kon wees. Aangesien die hoofsin boonop konstaterend en berigtend geformuleer is, sou daar op stilistiese vlak ook eerder ' $n$ aoristus as 'n perfektum goed gepas het. Ook die argument dat die papiri en

20 Ook Miller (1981:71-72) en Ashton (1986:173) dink in hierdie rigting.

21 Ashton $(1986: 171,175)$ en Theobald (2009:112-113) wys tereg hierop.

22 Vgl. BDR § 303.

23 W. Bauer (1933:11) beklemtoon tereg " $\pi \alpha \dot{\nu} \tau \alpha$ - alle Dinge ohne Ausnahme."

24 E. L. Miller (1989:17-44) bied 'n goeie oorsig oor die uitleggeskiedenis.

25 Vgl. H. Thyen (2005:68-71 en 2007:411-417). Hy gee die uitvoerigste begronding vir die argument dat die relatiewe bysin nog tot $v$. 3 behoort. 
oudste kodekse geen leestekens bevat het nie, kan nie werklik afbreuk doen aan die toedeling van die relatiewe bysin tot v. 4 nie: die aanvaarding van die moeiliker lesing was minstens tot Chrysostomos (Hom. 5.1) en Ambrosius (De fide 3.41-44) oorheersend. Die oplossing lê dus in 'n kundige grammatikale ontleding van die konstruksie. Die relatiewe bysin word sonder verwysing na enigiets anders in die nominatief geopen en met ' $n$ werkwoord in die perfektum afgesluit. Hierdie gebruik stem, net soos dit in v. 12 die geval is, ooreen met die in Grieks geldige casus pendens-konstruksie. In hierdie tipe konstruksie word 'n nominatief sonder verbinding en as 'n soort tese "an die Spitze des Satzes gestellt, obwohl das betreffende Nomen gar nicht Subjekt ist. Im Verlaufe des Satzes wird es dann als Pronomen im 'richtigen' Kasus wiederaufgenommen." ${ }^{26}$

Die moeilike vraag, naamlik wat die eintlike subjek van die sin is, moet nog aandag ontvang. Hierdie probleem is die hoofrede waarom soveel interpretasies kon ontstaan wat in die vroeë kerk deur die meerderheid as hereties gesien is. Hierdie interpretasies sluit in die Ariaanse, GnostiesManicheïese en die pneumatomachiese verstaanswyses. Die ware subjek kan grammatikaal óf in die uitdrukking $\dot{\varepsilon} v$ a $\tau \tau \tilde{\omega}$ óf in die werkwoord versteek wees. Laasgenoemde word deur 'n lidwoordlose predikaatsnomen - wat in hierdie geval daaropvolgend is - uitgebrei. In die eerste geval sou die geskapene die subjek wees en die vers sou dan ongeveer met "wat ontstaan het, daarin is lewe" ${ }^{27}$ vertaal moet word. Die ander variant sou wees dat die Logos as ware subjek in $\dot{\varepsilon} v$ aủ $\tau \tilde{\omega}$ verborge kan wees. Dan moet die vertaling lui "dit wat geword het (of: die gewordene) in Hom, die Logos, was lewe." ${ }^{28}$ Die derde oplossing, wat grammatikaal by verre beter pas, is dié een wat op die basis van die eerste twee verse, waarin $\tilde{\eta} \nu$ vier maal $\lambda$ óyos as subjek het, hier dieselfde subjek aanvaar. ${ }^{29}$ Verder mag 'n mens die perfektum in die relatiewe bysin nie miskyk nie. Dit het sy effek in die subjek of in die objek $^{30}$ en verwys dan na die "bestaande" wat uit die wording voortgekom het. Die vertaling sou dan lees "in die bestaande was Hy, die Logos, lewe."

26 G. Steyer (1975:123, §148 H, J); vgl. ook Moulton, Howard \& Turner (19631979:II, p. 423; IV, p. 427), N. Turner (1977:138-139) en BDR §466. Vgl. ook H. van den Bussche (1961:I, 124). Hy ontleed die sinskonstruksie ook soos hier voorgestel.

27 So vertaal o.a. Van den Bergh van Eysinga (1909:144).

28 Teen hierdie vertaling, wat o.a. ook deur Van den Bergh van Eysinga (1909:144) aanvaar is, het reeds F. Lücke (1833-1834:270-271), hoofsaaklik die beswaar gehad dat hierdie uitspraak v. 3 eintlik bloot herhaal en terselfdertyd ook die samehang met v. $4 \mathrm{~b}$ tot niet maak.

29 So tereg H. Gese (1977:163).

30 Vgl. BDR § 342 en H Lausberg (1984:195) 
Tog word hiermee nie die biologiese lewe bedoel nie, ${ }^{31}$ - laasgenoemde is deel van die basisuitrusting van die geskape leefwêreld - maar veel eerder die onfragmenteerbare lewe, wat slegs deur die Logos gegee kan word. Hierdie feit word in die volgende versdeel gepresiseer: volgens v. 3 is benewens die hemel (d.w.s. die son, maan en sterre as bronne van lig) ook die donkerte - ja, "alles" $(\pi \alpha ́ v \tau \alpha)$ - geskape. Dit waarvan hier egter gepraat word, is die aanbod van 'n besondere lewenskwaliteit. Hierdie aanbod word voortdurend, solank die wêreld ook al mag bestaan, opnuut gemaak en dit kan altyd, volhoubaar, opgeroep word: "Die lewe was die lig vir die mense" (vgl. ook 8:12). Hiermee is 'n belangrike oorgang na die daaropvolgende teksgedeelte geskep.

Vervolgens word die lot van hierdie spesiale lig ${ }^{32}$ in die wêreldgeskiedenis algemeen metafories getematiseer..$^{33}$ Die lig bly 'n ononderbroke (praesens!) aanbod aan die lewens- en mensewêreld. Tog word dit nie deur die "duisternis" aangeneem nie. Ook hier beteken "duisternis" nie die natuurlike donkerte nie; dit beskryf veel eerder die gevolge van die onafhanklikheid en selfstandigheid van die mens op 'n beeldryke manier. Hierdie onafhanklikheid bestaan daarin dat die mens in vryheid vir of teen die aanbod van die Logos kan kies. ${ }^{34}$ God het die wêreld, d.w.s. ook die duisternis, in vryheid geskape en vir sy skepping veel van Homself saamgegee - onder andere ook keusevryheid. God was naamlik by verre nie gedwing om die wêreld te skep nie. Hy het egter in vryheid daarvoor gekies. Nie net het Hy die Logos as Skeppingsmiddelaar in diens gestel nie, maar Hom ook, soos vv. 4-5 verduidelik, aan die geskiedenis van die mensdom as Begeleier, wat steeds bereid is om te help, geskenk. Die mense kan die "lig"-aanbod dankbaar aanneem - of dit laat. Alhoewel 'n

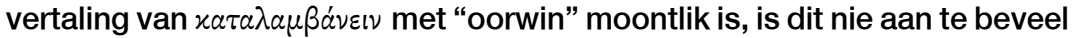
nie $^{35}$ omdat die duisternis dan as 'n aktiewe demoniese krag voorgestel sou wees. ${ }^{36}$ Die duisternis is egter, soos "alles" anders, ook geskep en daarom

31 Dieselfde word duidelik in v. 13, vir sover hierdie vers nie eksegeties as glos gesien word nie.

32 Vgl. Miller (1989:64): " $\omega \eta$ ' in the Johannine Gospel and Epistles never designates natural, physical life."

33 Daarom die praesens in v. 5!

34 Dit is 'n vroeg-Joodse, d.w.s. kontemporêre probleem; vgl. Sir. 15:15-17; CD II 15-17; 2 Bar. 54:19; 4 Esr. 3:20-21. Die etiese komponente van die metafoor "duisternis" word reeds in Jes. 5:20 getematiseer.

35 Teen Theobald (2009:116). Sy retoriese vraag bring hier sy interpretasiedilemma aan die lig. 15:18-20 praat 'n ander taal.

36 Von Harnack (1892:219-220) het dit uitvoeriger begrond: "Wider die Deutung

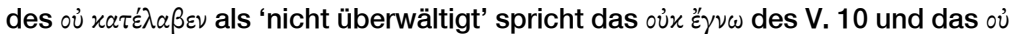

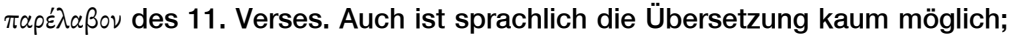
endlich empfiehlt es sich auch deßhalb nicht, weil sie $\dot{\eta} \sigma x o \tau i ́ a$ zu einem Activum 
positief gedui. Tog neem dit die steeds vryblywende aanbod van die Logos vanuit eie, selfstandige oorwegings nie aan nie. Uit die perspekief van die outeur is dit die oorsaak van talle menslike en maatskaplike probleme. Die feit dat die mens vry is om tussen goed en kwaad te kies, stel die eintlike drama daar en genereer 'n tragiek wat die hele geskiedenis van die mensdom oorskadu (vgl. 3:19-20; 9:39-41; 15:18-16:4; 17:14).

Die wisseling in v. 5 tussen die opvallende duratiewe praesens "en die lig skyn in die duisternis" na 'n narratiewe aoristus ${ }^{37}$ "en die duisternis het dit nie begryp nie" veronderstel twee dinge: enersyds, dat die bestendige lewensaanbod van die Logos vir die verdere geskiedenis van die ganse skepping sal geld. Dit sou 'n mens vandag 'n spiritueel-intellektuele evolusie kon noem. Andersyds veronderstel die grammatikale tydswisseling dat hierdie aanbod in bepaalde historiese situasies of tydperke van die hand gewys is en ook nog sal word. Een sodanige afwysing word kortliks in die volgende verse (6-13) beskryf. Sodoende is met v. $5 \mathrm{~b}$ die weg voorberei vir 'n toepassing op ' $n$ histories era. Hierdie era kan wel net een mosaïeksteen in die wyd uitgestrekte wêreldgeskiedenis wees. Tog verteenwoordig dit, ten spyte van alle weerstand vanuit die eie kamp, 'n goeie gevolg, hoe beskeie ook al. Hierdie goeie gevolg dui boonop op 'n kwalitatiewe vooruitgang vir alle daaropvolgende historiese tydperke.

Hierdie periodisering van die verloop van die geskiedenis word aan die einde van die Evangelie - metafories passend - nogeens duidelik aangedui. Daar word naamlik uitdruklik berig van die bloed en water wat, teen elke ervaring in, uit die sy van Jesus gevloei het (19:34). Hierdie twee lewensnoodwendige substansies dui - nie net hier nie - in 'n oordragtelike sin op twee heilsaspekte wat ten spyte van die dood van Jesus nietemin vir altyd behoue sal bly. Eerstens verwys dit na die Gees

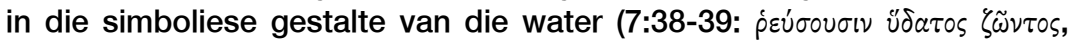
d.w.s. die "leweskeppende water" [vgl. o.a. Sag. 14:8] is die Heilige Gees). Verder simboliseer bloed in die Bybelse tradisie die lewe, wat alleen aan die Here behoort (Deut. 12:16, 23-25; Lev. 17:10-14). Die substansies water en bloed, wat uit die liggaam van Jesus vloei, simboliseer gevolglik die voortduur van die Goddelike aanbod van heilige Gees en oneindige Lewe (v. 4) in die menslike wêreld, ook ná die dood van Jesus. ${ }^{38}$

macht." Die vertaling met "oorweldig", wat sedert Origenes bekend is, pas ook nie werklik by 12:35 - waarmee dikwels geargumenteer word - nie.

37 Holtzmann (1926:10) praat van 'n "Aorist der Erfahrungswahrheit"; "die göttliche Wirksamkeit wird von der Welt nicht verstanden."

38 G. van Belle (1999:101) het hierdie twee belangrike aspekte binne 'n groter Christologiese samehang geplaas: "Voor de evangelist verwijst het uitvloeien van bloed en water naar Jezus als Messias en Zoon van God: bloed verwijst naar de zondevergeving, water naar geestesgave, beide bron van eeuwig 
Een hoofstuk verder (hfst. 20) word intertekstueel weer eens, soos in hierdie deel van die Proloog (v. 1-5), na die skeppingsberig (Gen 2:7) terugverwys. Dit gebeur wanneer die Opgestane aan die dissipels verskyn, oor hulle blaas en hulle op hierdie wyse die Gees-Parakleet, die ware Lewensasem, ter wille van hul verdere opdrag spesiaal ontvang (vgl. 20:22 met 14:16; 15:26). Met hierdie gebeurtenis word die nuutskepping van die eerste gelowiges voltrek. Hulle word daaropvolgend met hierdie Geestestoerusting uitgestuur, net soos die Vader Jesus Christus tevore uitgestuur het. Jesus is op sy beurt soos die lam op Jom Kippur, wat die sonde van die wêreld dra (1:29), in die wêreld ingestuur. Ook Hy was oorvloedig met die Heilige Gees toegerus (vgl. 1:32-33 met 3:34). Die aanbod van 'n oneindige lewe, gerig deur die Logos, bestaan dus ook ná Paasfees voort (17:20-21). Die tese van 'n Christologiese inenging by v. 5 (of vanaf v. 4?), bevestig sigself hoegenaamd nie. Dit beteken dus nie dat v. 5 slegs betrekking het op die reeds begonne werking van die Geïnkarneerde nie,$^{39}$ maar wel dat v. 5 hierdie aangevange werk insluit.

\section{WAAROM DIE NAAM LOGOS?}

Die ou vraag waarom hierdie Skeppingsmiddelaar en -begeleier die Logosnaam gekry het, moet nog aandag geniet. In die navorsingsgeskiedenis het vyf voorgestelde oplossings vir verskillende afleidings van die naam uitgekristalliseer: 1. 'n Hipostase van God; 2. die nominalisering van die tienvoudige "en God het gesê" in die skeppingsberig; ${ }^{40} 3$. die vroegJoodse wysheid; ${ }^{41} 4$. die Platoniserende uitleg ${ }^{42}$ van die skeppingsverhaal

leven.” Die beperking van die simbool van bloed tot slegs sondevergifnis wil ek graag oper sien. Die lewensoffer van Jesus open vir alle en nie net vir talryke nie, die weg tot oneindige lewe.

39 Dit word byvoorbeeld in navolging van R. Bultmann en E. Käsemann in beginsel deur H. Thyen (1974:54, 59-61) bevestig. In sy artikel (Thyen 1980:170-171) en in sy kommentaar (Thyen 2005:75) brei hy hierdie uitspraak tot v. 4 uit. Ten gunste van so 'n interpretasie het Von Harnack (1892:218-219) reeds hierdie oorgang vanaf Logos asarkos tot sy geskiedkundige uitwerking betoon. Daarteen, vgl. o.a. R. Schnackenburg (1958:33) en Ashton (1986:174).

40 So o.a. Thyen (2005:66). S.M. Olyan (1993:93-94) skryf as volg oor die vroegJoodse agtergrond van hierdie voorstelling: "In both cases, an attribute of the divine (the arm, the word) is treated figuratively as the locus of divine activity; divine actions are particularized in an attribute, be it the arm, the word, or the name of God ... abstract attributes tend on the whole to be described as if they were active agents present with, but distinct from, God; in other words, as if they were other divine beings, not unlike angels."

41 Byvoorbeeld Haenchen (1980:138-140) en Ashton (1986:162, 168).

42 Vgl. Philo, all. 1.21; 3.96, 171; som. 1.75, 85. 230; op. 24, 29-31, 36; spec. 1.81. 
deur Philo van Alexandrië ${ }^{43}$ en 5 . Gnostiese skeppingsmites. ${ }^{44}$ Die laaste voorstel is reeds geruime tyd nie meer met groter welslae as voorheen beredeneer nie. Nadat die tese van 'n voor-Christelike Gnosis laat vaar is, het hierdie voorstel ook hoogs onwaarskynlik geword. Dit kan dus met goeie reg uit hierdie bespreking uitgesluit word. Ook die voorstel wat lank voorkeur geniet het, naamlik dat die naamsafleiding uit die Filonese uitleg van die skeppingsberig stam, oortuig nie werklik nie. Selfs Aall $(1899: 87$ vn. 82; vgl. 93, 145) wat reeds baie vroeg gemeen het dat daar heelwat aanduidings gevind kan word dat die Proloog van Filo stam, kan nie anders nie as om toe te gee: "Der Logos des Philo war ein Prinzip, der Sohn Gottes im vierten Evangelium zunächst eine geschichtlich gegebene Persönlichkeit." 45 Die naamsafleiding uit die vroeg-Joodse wysheidsliteratuur $^{46}$ besit, ten spyte van talle voor die hand liggende parallelle voorstellings, ook ' $n$ wesenlike tekortkoming. Die wysheid is in die Hebreeus (Chokma), sowel as in Grieks (Athena) en Latyn (Minerva), oral ' $n$ vroulike vorm en sy "inkarneer" wel in die Torah, in die tempel of in Israel as 'n geheel, maar nêrens in 'n persoon nie. Die Logos word egter met Jesus Christus (v. 17) as persoon geïdentifiseer. Ook met die eerste voorstel is daar min uit te rig, alhoewel dit in die ouer navorsing ${ }^{47}$ met tye die keuse was. Hierdie voorstel kan sigself wel op die Hebreeuse Bybel beroep wanneer Ps. 33:6; 107:20; 147:15,18; Jes. 40:8; 55:10-11; Wys. 9:1; 16:12; 18:15-16 aangehaal word. In al hierdie teksverwysings word die skeppingswoord skynbaar gepersonifiseer. 'n Mens kan egter die objektivering van die woord nie sonder meer op v. 1b toepas nie omdat daar in laasgenoemde van 'n Persoon in die milieu divin gepraat word, wat reeds 'n Gegenüber vir God is. Hiermee bekom die tweede voorstel tot 'n oplossing die grootste waarskynlikheidswaarde. Die Logos, wat na God toegewend was, het in hul gesprek sy skeppingswoord gehoor, hul gemeenskaplike, onvernietigbare konsensus van interesse ten opsigte van die beplande skepping ontdek, en hierdie konsensus planmatig en eksak deurgevoer. Daardeur kry Hy met reg by die outeur die kenmerkende naam Logos.

43 Theobald (2009:118-119; 1992a:217, 247-295; 1992b:41-87) verbind punt 2 met punt 3. Reeds C.H. Weisse (1838:VI,186) het egter opgemerk dat die bewyse vir 'n aanwending van Philo meer as onseker is.

44 O.a. R. Bultmann (1923:3-26; heruitgegee as 1967:10-35).

45 "Die Logos van Philo was 'n prinsipe, die Seun van God in die Vierde Evangelie aanvanklik 'n histories gegewe persoonlikheid."

46 Job 12:13; 28:12-13; Bar. 3:9-4:4; 9:6; [Ps. 104:24]; Wys. 7:22-23; 9:9-10; hfst 10; Sir 1:1,4; hfst. 9; 24:1-2; Spr 8:22-9:6; ethHen. 42:1-2; SlawHen. 30:8; Aristobulus 2.69-73; Phokylides 129-131.

47 Vgl. die oorsig in W. Sanday (1905:185-204, 186-188). 
'n Vertaling van Johannes 1:1-5, gebaseer op bogenoemde analise, sal dus so daaruit sien:

1 In die oerbegin was die Logos, en die Logos was na God toe gewend, en "God" [vir die wêreld] was die Logos.

$2 \mathrm{Ja}$, Hy was na God gewend in die oerbegin.

${ }^{3}$ Alles het deur Hom geword en sonder Hom het niks geword nie.

${ }^{4}$ In die Bestaande was Hy lewe, en die lewe was die lig vir die mense.

${ }^{5}$ En die lig skyn in die donkerte en die donkerte het dit nie (aan) gegryp nie.

\section{SAMEVATTEND}

In Johannes 1:1-5 word veel oor God self gekommunikeer. Hy is die basiese Draer van die handelinge in die Proloog. Dit was sy kreatiewe idee om die wêreld te skep. Hy laat, uit Johannese perspektief, van die oeraanvang af 'n Ander, 'n Gegenüber, toe, soek Hom in gesprek op, wy Hom in sy plan in en vertrou aansluitend sy skeppingswerk aan Hom toe. Daarna laat Hy Hom, van wie die naam Logos hoogs waarskynlik van die tienvoudige Bybelse skeppingswoord "en God het gesê" afgelei is, sy werk dwarsdeur die geskiedenis behoedsaam begelei. God doen dit deurdat $\mathrm{Hy}$ die Logos Goddelike lewe en lig laat bemiddel en dit as hulp vir 'n geslaagde hantering van die lewe laat dien. God staan dus in trou vas en onwrikbaar by sy skeppingsprojek. Lankmoedig en geduldig laat Hy die lig skyn, alhoewel dit - histories gesien - in 'n bepaalde tyd en in 'n bepaalde plek deur die oorweldigende meerderheid van die menslike wêreld nie "aangegryp" word nie. So sou die skepping op dieselfde manier tot dié kommunikatiewe Gegenüber vir God kon word wat Hy sou wou hê, maar die skepping is daarin sy eie grootste struikelblok, omdat dit (nog) nie daarvoor toeganklik was nie. As gevolg hiervan definieer vv. 1-5 a priori die voorvereistes en die blywende geldigheid van die skeppingsdoel deur 'n voortdurende spiritueel-intellektuele revolusie, soos in die res van die Proloog ook duidelik gemaak word.

\section{BIBLIOGRAFIE}

\section{AALL, A.}

1899. Der Logos: Geschichte seiner Entwicklung in der griechischen Philosophie und der christlichen Litteratur. Bd. II: Geschichte der Logosidee in der christlichen Litteratur. Leipzig: Reisland. 
Ashton, J.

1986. The transformation of wisdom: A study of the Prologue of John's Gospel. NTS 32:161-186.

BARRETT, C.K.

1982. Essays on John. London: SPCK.

BAUER, W.

1933. Das Johannesevangelium. Tübingen: Mohr-Siebeck. HNT 6.

Blass, F., Debrunner, A. \& Rehkopf, F.

2001. Grammatik des neutestamentlichen Griechisch. Göttingen: Vandenhoeck \& Ruprecht.

Brox, N.

1996. Terminologisches zur frühchristlichen Rede von Gott. BAW.PH 1:3-46.

2000. "Gott" mit oder ohne Artikel. Origenes über Joh 1,1. In: F. Dünzl, A. Fürst \& F.R. Prostmeier (eds.), Das Frühchristentum. Schriften zur Historischen Theologie (Freiburg/Wien/Basel: Herder), pp. 423-429.

Bultmann, R.

1923. Der religionsgeschichtliche Hintergrund des Prologs zum Johannesevangelium. In: H. Gunkel (Hrsg.) Eucharistion. FS (Göttingen: Vandenhoeck \& Ruprecht, 2), pp. 3-26.

1967. Exegetica. Tübingen: Mohr Siebeck.

BusSE, U.

2002. Das Johannesevangelium. Bildlichkeit, Diskurs und Ritual. Mit einer Bibliographie über den Zeitraum 1986-1998. Leuven/Paris/Sterling: Peeters. BETL 162.

CARTER, W.

1990. The Prologue and John's Gospel: Function, symbol and the definitive Word. JSNT 35-58.

Colwell, E.C.

1993. A definite rule for the use of the article in the Greek New Testament. JBL 52:12-21.

Culpepper, R.A.

1983. Anatomy of the Fourth Gospel. A study in literary design. Philadelphia: Fortress.

DÖRRIE, H.

1979. Der Prolog zum Evangelium nach Johannes im Verständnis der älteren Apologeten. In: A.M. Ritter (red.), Kerygma und Logos. FS C. Andresen (Göttingen: Vandenhoeck \& Ruprecht), pp. 136-152. 
Gese, H.

1977. Der Johannesprolog. In: H. Gese, Zur biblischen Theologie: Alttestamentliche Vorträge (München: Kaiser, BEvT), pp. 152-201.

GiBLIN, C.H.

1985. Two complementary literary structures in John 1:1-18. JBL 104:87-103.

HAENChen, E.

1980. Das Johannesevangelium. Ein Kommentar aus den nachgelassenen Manuskripten herausgegeben von Ulrich Busse mit einem Vorwort von James M. Robinson. Tübingen: J.C.B. Mohr (Paul Siebeck).

HARNER, P.B.

1973. Qualitative anarthrous predicate nouns: Mark 15:39 and John 1:1. JBL 92:75-87.

HeitmüLleR, W.

1908. Das Evangelium des Johannes. Göttingen: Vandenhoeck \& Ruprecht. Die Schriften des Neuen Testaments 2.

HoltzmanN, H.J.

1926. Das Neue Testament, II. Giessen: A. Töpelman.

Holtzmann, O.

1887. Das Johannesevangelium untersucht und erklärt. Darmstadt: Waitz.

Korting, G.

1989. Joh 1,3. BZ 33:97-104.

LAUSBERG, H.

1984. Der Johannes-Prolog: Rhetorische Befunde zu Form und Sinn des Textes. Göttingen: Vandenhoeck \& Ruprecht. NAWG 5.

LÜCKE, F.

1833-1834. Commentar über das Evangelium des Johannes. Bonn: Eduard Weber.

MiLleR, E.L.

1981. The Logos was God. EvQ 53:65-77.

1989. Salvation history in the Prologue of John: The signification of John 1:3/4. Leiden: Brill. SuppINT 60.

Moulton, W.F., Howard, W.F. \& Turner, N.

1963-1979. A Grammar of New Testament Greek, II. Edinburgh: T \& T Clark.

OLYAN, S.M.

1993. "A thousand thousands served him": Exegesis and the naming of angels in ancient Judaism. Tubingen: J.C.B. Mohr. 
Osten-SACKen, V.D.

1994. Logos als Thora? Anfragen an eine neue Auslegung des Johannesprologs. Kirche und Israel 9:138-149.

Prostmeier, F.R. \& LonA, H.E. (eds.) 2010. Logos der Vernunft - Logos des Glaubens. Berlin: Vandenhoeck \& Ruprecht. MSt 31.

SANDAY, W.

1905. The criticism of the Fourth Gospel. Oxford: Clarendon.

SCHNACKENBURG, $R$.

1958. Das vierte Evangelium und die Johannesjünger. Historisches Jahrbuch 77:21-38.

SCHNEIDER, J.

1978. Das Evangelium nach Johannes. Berlin: Evangelische Verlagsanstalt. THKNT.S.

ScHWANK, B.

1996. Evangelium nach Johannes erläutert für die Praxis. St. Ottilien: EOS-Verlag.

SCHWARTZ, E.

1907/1908. Aporien im vierten Evangelium. In: Nachrichten von der Königlichen Gesellschaft der Wissenschaften zu Göttingen. Philologisch-historische Klasse, pp. 115-148, 342-372; 497-560.

SteYer, G.

1975. Satzlehre des neutestamentlichen Griechisch. Gütersloh: G. Mohn.

THEOBaLd, M.

1992a. Die Fleischwerdung des Logos. Münster: Aschendorf.

1992b. Gott, Logos und Pneuma: "Trinitarische" Rede von Gott im Johannesevangelium. In: H.-J. Klauck (red.), Monotheismus und Christologie (Freiburg: Herder, QD 138), pp. 41-87.

2009. Das Evangelium nach Johannes (Kap. 1-12). Regensburg: Pustet. RNT. NF 4.2.

THYEN, $\mathrm{H}$.

1974. Aus der Literatur zum Johannesevangelium. TR 39:1-69, 222-252, 289-330.

1980. Das Heil kommt von den Juden. In: D. Lührmann \& G. Strecker (reds.), Kirche. FS G. Bornkamm (Tübingen: Mohr), pp. 163-184.

2005. Das Johannesevangelium. Tübingen: Mohr-Siebeck. HNT 6.

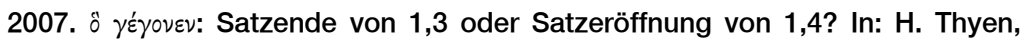
Studien zum Corpus Johanneum (Tübingen: Mohr-Siebeck), pp. 411-417.

TURNER, N.

1977. Grammatical insights into the New Testament: St. John. Edinburgh: T \& T. 
VAn Belle, G.

1999. "Bloed en water" in Joh 19,34. In: J. Haers, T. Merrigan \& T. de Mey (reds.), "Volk van God en gemeenschap van de gelovigen": Pleidooien voor een zorgsame kerkopbouw. FS R. Michiels (Averbode: Altiora), pp. 89-111.

Van Den Bergh Van Eysinga, G.A.

1909. Zum richtigen Verständnis des johanneischen Prologs. Protestantische Monatshefte 13:143-150.

Van Den Bussche, H.

1961. Het vierde Evangelie. Tielt/Den Haag: Lannoo.

Von Harnack, A.

1892. Ueber das Verhältnis des Prologs des vierten Evangeliums zum ganzen Werk. ZTK 2:189-231.

Von WaHLDE, U.C.

2010. The Gospel and Letters of John. Grand Rapids: Eerdmans. Eerdmans Critical Commentary.

WEDER, $\mathrm{H}$.

2008. Ursprung im Unvordenklichen: Eine theologische Auslegung des Johannesprologs. Neukirchener. BTS 70.

WEISS, B.

1893. Das Johannesevangelium. Göttingen: Vandenhoeck \& Ruprecht. KEK.

1911. Der Gebrauch des Artikels bei den Gottesnamen. Theologische Studien und Kritiken 84:319-392, 503-538.

1912. Das Johannesevangelium als einheitliches Werk geschichtlich erklärt. Berlin: Trowitzsch.

WeISSE, C.H.

1838. Die evangelische Geschichte kritisch und philosophisch bearbeitet. Leipzig: Breitkopf und Hartel.

Westcott, B.F. 1900. The Gospel according to St. John: The Authorised Version with Introduction and Note, 1900. London: John Murray.

Trefwoorde

Logos

Johannes Proloog

Christologie

Skepping
Keywords

Logos

Prologue of John

Christology

Creation 